\title{
20
}

\section{Crowdfunding Education: Objectives, Content, Pedagogy, and Assessment}

\author{
Rotem Shneor and Bjørn-Tore Flåten
}

\section{Introduction}

Despite its rapid growth, the practice of online crowdfunding remains a relatively novel phenomenon. Earlier studies have suggested that for the crowdfunding industry to gain greater traction, as well as develop along healthy and ethical lines, it is necessary to educate the public about its challenges and risks, as well as its merits and benefits (De Buysere et al. 2012). Such efforts are aimed at both raising awareness, as well as developing relevant skillsets towards successful crowdfunding practice (De Voldere and Zeqo 2017).

While much information and advice about crowdfunding are freely available online, often their origins, neutrality, rigour, and comprehensiveness may all be questionable. Thus far, a substantial part of educational efforts has taken the form of support services provided by crowdfunding platforms. Such services include a wide range of approaches

R. Shneor $(\bowtie) \bullet$ B.-T. Flåten

School of Business and Law, University of Agder, Kristiansand, Norway e-mail: rotem.shneor@uia.no; bjorn-tore.flaten@uia.no 
from dedicated training materials to informative Questions and Answers sections on their websites (e.g. The Kickstarter Blog, Indiegogo Help \& Support, Prosper Help Center, OurCrowd Knowledge), as well as invited seminars by platform representatives in organizations and industry events.

However, while platforms are encouraged to provide information in order to support the onboarding of users for their long-term sustainability and profitability, crowdfunding education often involves non-platform specific information and skillsets that can be applied when using any platform. Furthermore, taking into consideration that most platforms are young and resource-constrained, platforms have limited incentives to pay for a public good such as crowdfunding education. As a result, information provided by such entities may be partial and biased towards their own commercial interests.

Some efforts to overcome these challenges have manifested in educational support provided by crowdfunding industry associations rather than by individual platforms. However, only a minority of industry associations offer such training services (Jegelevičiūtė and Valančienè 2015). Such interventions, while helpful, are still coloured by industry interests. Other sources include the little and very limited advice published on government websites (e.g. Business.gov.au 2019; Consumer.ftc.gov 2019; European Commission n.d.).

Accordingly, there is a growing need for unbiased and academically sound educational programmes in crowdfunding for prospective campaign creators and backers. Thus far, the practice of crowdfunding education within formal educational institutions has mostly involved incorporating it as an 'exotic' sub-theme under more general courses on entrepreneurship, digital marketing, as well as financial technology (hereafter 'FinTech') and innovations in finance. Very few institutions have developed complete course programmes specifically dedicated to crowdfunding.

Hence, this chapter presents first insights on a dedicated crowdfunding course in higher education. It does so by presenting a case of a credit awarding academic 'Crowdfunding Lab' course (Alois 2018) that was developed at the University of Agder (hereafter 'UiA'). This case serves as an illustrative example of how such programmes can be designed and implemented while outlining course objectives, contents, and pedagogy. 
A summary of the feedback from the course evaluation provided by the students will also be included. Later, a discussion highlighting opportunities for its further development will be outlined. This chapter concludes with suggestions for research, as well as implications for educators and trainers.

\section{Why Do We Need Crowdfunding Education?}

Crowdfunding has emerged at the intersection of two global trends. First, the growth in popular use of technologies enabling digital communication, commerce, and finance has become more pervasive than ever before. Indeed, digitalization has become a major theme for educational and practical concerns in most occupations, and equipping students with relevant knowledge and skillsets has become the call of the hour (Brocato et al. 2015; Harrigan and Hulbert 2011). While digitization brings many operational benefits and efficiencies, they also involve challenges requiring the development of relevant skills in using them.

At the same time, crowdfunding emerged as an alternative source of project funding following the global financial crisis, when traditional financing dried up (Bruton et al. 2015) and public funding faced major cutbacks in many countries (Boeuf et al. 2014). Hence, the use of new FinTech solutions for fundraising seemed to address both emerging market gaps and opportunities, while strengthening notions of individual empowerment (Chaney 2019) when interacting and transacting with businesses and organizations. In this respect, FinTech solutions both complement existing financing channels and fill market gaps that have been underserved by traditional institutions (Haddad and Hornuf 2019).

Accordingly, education should reflect the current environment for project management, adapt to new realities, and equip graduates with relevant knowledge and skills. Relevance here refers to both preparing students for the tasks of work life, as well as for the general contextneutral cultivation of excellence (Simpson 2013) often manifested in the acquisition of core skills. Crowdfunding represents one development in our ever more digital lives, which may be relevant for a wide range of students across disciplines, as it is applicable for the financing of 
commercial, cultural, humanitarian, social, civic, legal, political, and technological initiatives and projects. Hence, education on a novel phenomenon like crowdfunding serves as an ideal basis for exposing students to what is referred to as 'twenty-first century skills', such as media and technology literacy, communication, and collaborative problem solving (Griffin and Care 2014).

For this purpose, Crowdfunding Education is hereby defined as a collection of teaching schemes that inform, train, and educate anyone interested in the responsible planning and execution of crowdfunding campaigns towards project fundraising and/or in responsibly contributing to them financially or otherwise. Here, it is worth stressing some important aspects of this definition. First, the definition stresses that knowledge and skillsets need to be developed by both parties to a crowdfunding engagement - the fundraiser and the backer. Besides the fact that a fundraiser for one project may be a backer of another, both parties need to develop skills in assessing and interacting with each other throughout a crowdfunding process. Second, it stresses the importance of responsibility in crowdfunding engagement to ensure the ethical and non-harmful practice of crowdfunding.

\section{Designing a Crowdfunding Course Programme}

While one may wish to build on existing knowledge when designing a course, research on crowdfunding education is virtually non-existent. Nevertheless, research on education in tangent fields such as entrepreneurship, marketing, and financial education suggests the importance of a programme's objectives, content, pedagogy, and assessment procedures (e.g. Crittenden and Crittenden 2006; Fox et al. 2005; Mwasalwiba 2010). This section addresses these aspects with respect to crowdfunding education, as illustrated by the UiA Crowdfunding Lab case, and will be followed by a discussion highlighting opportunities for its further development. 


\section{Case in Focus: The UiA Crowdfunding Lab}

The Crowdfunding Lab course at UiA is a master's level elective course offered at the School of Business and Law to Norwegian and international exchange students. The reason for using the term 'Lab' in the course's name is based on the pedagogic approach of exposing the students to a social lab setting, in which they work with real cases and experiment with ideas about directions they should take. The course is taught in English, and participants meeting course requirements receive 7.5 credit points according to the ECTS (European Credit Transfer and Accumulation System). It was launched as a pilot in 2018 in collaboration with and co-sponsorship of Innovation Norway, which is the Norwegian government's main instrument for innovation and development of Norwegian enterprises and industry (Innovation Norway n.d.). In 2019 it entered the list of courses as a regular elective course and became fully funded by the university.

\section{Course Objectives}

Learning objectives describe what course participants are expected to learn and the behaviours that will demonstrate such learning (Graeff 1998). Hence, course objectives can be divided between those targeting knowledge acquisition outcomes and those targeting skill development outcomes (Crittenden and Crittenden 2006). Others suggested, based on the context of entrepreneurship education, distinguishing between objectives termed as education 'for' versus education 'through' (Mwasalwiba 2010), where the former suggests education stimulating certain behaviour (e.g. starting a new venture), while the latter suggests using behaviour for the acquisition of understanding and skills (e.g. using new venture creation to acquire business skills).

In the current versions of the UiA Crowdfunding Lab course description and syllabus one can identify both knowledge and skill acquisition outcomes in the specified course objectives. First, in terms of knowledge acquisition objectives, the course aims for students to demonstrate familiarity with (1) crowdfunding principles, types, and models and discuss 
the differences between them; (2) key actors in crowdfunding markets, including platforms types, functionalities, and business models; (3) the role of context (industry, national, and international issues) in crowdfunding practice and patterns; (4) success and failure factors in crowdfunding campaigns; as well as (5) ethical dilemmas in crowdfunding and possible mechanisms for mitigating them. Second, in terms of skill development, the course aims for students to demonstrate skills in (1) crowdfunding campaign planning, as well as component and process development; (2) crowdfunding campaign budget and financial planning; and (3) crowdfunding campaign marketing and promotional planning.

Accordingly, the above-stated objectives relate more to the education 'through' rather than 'for' types of objectives, where crowdfunding campaign development is used as a setting for the acquisition of understanding and skills related to crowdfunding campaign management. In this sense, expected outcomes do not require participants to fundraise or contribute financially to crowdfunding campaigns after the course, but rather to acquire knowledge and skills that may prove helpful for those who may wish to engage in crowdfunding activities in the future. It is therefore more concerned with developing self-efficacy (Bandura 1986), as in one's perception of his or her own ability to perform a behaviour, which in our context will be an engagement in crowdfunding either as a fundraiser, backer, or both. Nevertheless, according to the Theory of Planned Behaviour (Ajzen 1991), higher levels of self-efficacy will enhance the likelihood of developing intentions to engage in crowdfunding, as well as behaviour in such actual engagements (Shneor and Munim 2019).

A noteworthy exception here is with respect to external organizations that voluntarily sign up as cases for what is often referred to as 'student consultancy projects' (Thomas and Busby 2003). Here, organizations seek assistance from students in developing crowdfunding campaigns for both commercial and non-commercial initiatives. Such participation in the course does come with an unstated expectation of future crowdfunding campaigning by the case organizations, hopefully building partially or fully on the students' work and inputs. Such benefits from collaborations with industry fall under the school's community outreach and 
regional impact efforts (De Faoite et al. 2003) and do not constitute learning objectives in themselves.

For educators, it is worth noting the effort this kind of involvement with external organizations requires. Here, the lecturers' long-time engagement with the crowdfunding industry made it possible to attract key stakeholders to the course. Moreover, engagement with the local industry (e.g. start-ups and SMBs) makes it possible to attract potential businesses and organizations as real-life cases for the course. The benefits of joining are that they receive a complete campaign and execution plan for it, which they later can launch and follow. Furthermore, case firm representatives gain insight in the theory and practice of crowdfunding, as they have a unique opportunity to interact with the students and learn from their perspectives. All this is clearly communicated to the companies before the course starts, when outlying expectations to prospective case participants. It is imperative that they fully commit to such participation, in terms of communication and meetings with students throughout the course, while allowing them enough freedoms to make their own assessments and strategic choices.

\section{Content}

Course content is organized in modules, each representing a list of topics covered in class and the reading lists that accompany them (Brocato et al. 2015; Crittenden and Crittenden 2006). Table 20.1 presents UiA Crowdfunding Lab's course modules and the list of core topics they cover.

The course starts with an introductory module defining crowdfunding, its origins, value propositions, and various models. Such introduction is accompanied by a review of the current state of the crowdfunding industry, as well as the FinTech industry more generally. The two modules that follow present practical considerations for campaign planning and execution including crowdfunding model and platforms choice, campaign budget management, as well as campaign marketing and promotions. The fourth module places crowdfunding in the context of social networking and social capital while explaining the logic and mechanisms 
Table 20.1 Crowdfunding course modules and topics

\begin{tabular}{|c|c|}
\hline Module & Topics \\
\hline Introduction to crowdfunding & $\begin{array}{l}\text { Crowdfunding definitions, value propositions, } \\
\text { and models } \\
\text { Crowdfunding process and stages } \\
\text { State of the crowdfunding industry locally and } \\
\text { internationally } \\
\text { Crowdfunding in context of the FinTech } \\
\text { industry }\end{array}$ \\
\hline Campaign budget and finance & $\begin{array}{l}\text { Traditional and alternative sources of finance } \\
\text { Fundamentals of project budget management } \\
\text { Fundamentals of financial planning } \\
\text { Crowdfunding-specific costs }\end{array}$ \\
\hline $\begin{array}{l}\text { Campaign creation and } \\
\text { planning }\end{array}$ & $\begin{array}{l}\text { Considerations for crowdfunding model choice } \\
\text { Success factors in crowdfunding campaign } \\
\text { Crowdfunding campaign marketing and } \\
\text { promotional strategies } \\
\text { Meeting creators of successful crowdfunding } \\
\text { campaigns }\end{array}$ \\
\hline Networks and social capital & $\begin{array}{l}\text { Network units, structures, and value } \\
\text { Social capital } \\
\text { Social networking and word-of-mouth } \\
\text { Online communities and social networking } \\
\text { sites }\end{array}$ \\
\hline Crowdfunding platforms & $\begin{array}{l}\text { Platform products, services, and responsibilities } \\
\text { Considerations for choosing the right platform } \\
\text { Meeting platform representatives }\end{array}$ \\
\hline Crowdfunding regulation & $\begin{array}{l}\text { Current state of crowdfunding regulation in } \\
\text { Norway } \\
\text { Current state if crowdfunding regulation in } \\
\text { Europe } \\
\text { Future developments in crowdfunding } \\
\text { regulations }\end{array}$ \\
\hline $\begin{array}{l}\text { Ethical considerations in } \\
\text { crowdfunding }\end{array}$ & $\begin{array}{l}\text { Ethical dilemmas in crowdfunding } \\
\text { Potential ethical pitfalls by stakeholder } \\
\text { Potential remedies for mitigating moral hazard } \\
\text { in crowdfunding }\end{array}$ \\
\hline $\begin{array}{l}\text { Presentation pitching and } \\
\text { video skills }\end{array}$ & $\begin{array}{l}\text { Best practice in project presentation } \\
\text { Best practice in amateur video production }\end{array}$ \\
\hline
\end{tabular}


of value creation through the build-up and mobilization of social relations.

The remaining modules do not require following in any specific order but should follow the first four. Here, the fifth module presents the roles and responsibilities of crowdfunding platforms, as well as allows students to be familiarized with such concrete service providers, the services they offer, their campaign approval procedures, and their respective systems and web interfaces. The sixth module reviews the current status and dynamic evolution of regulation overseeing the different models of crowdfunding both in Norway and in Europe. The seventh module stresses the importance of responsible industry development via a critical review of ethical dilemmas and potential pitfalls stakeholders may face when engaging in crowdfunding, as well as potential remedies for addressing them. And the eighth module involves concrete advice on how to improve and develop presentation pitching skills including the effective use of multimedia and best practice advice in the creation of such elements.

In the absence of a textbook designed for crowdfunding courses, a reading list has been used including a series of academic articles that were clustered around core themes deemed as both fundamental and accessible in terms of reading difficulty. Course materials incorporated the readings and lecture slides developed by the instructors for this course. Here, it is important to note that the reading list served more as supplementary material rather than instructional material, providing students with the opportunity to expand their understanding, as well as familiarise themselves with some research within the area of crowdfunding. All articles were made available to course participants via the university's digital course management system, and each participant was required to summarize one article and share such summary with other course participants.

Here it is important to note that creating an open and supportive, yet demanding, learning environment is crucial for the success of such a course. The students meet face-to-face for a full day of lectures and labwork once a week. A flexible lecture room with desks, presentation equipment, and black and/or white boards are used in order to present the key modules and topics. Close to the lecture room, smaller group rooms 
make it possible for the students to break out in groups and work on their project. The lecturers can then easily walk from group to group and supervise the project work. The students can also learn from each other, as well as from the different companies that regularly communicate with the students and vice versa. The flexibility between the lecture room and the group rooms facilitates the dynamic shifts between lecturing, group work, mentoring, and pitching.

\section{Pedagogy}

Teaching methods are classified as either traditional and passive or nontraditional and active (Michel et al. 2009; Wingfield and Black 2005). Passive learning is when students passively receive information from the instructor and internalize it through some form of memorization (Wingfield and Black 2005), while active learning involves instructional strategies where students are doing things and think about the things they are doing (Bonwell and Eison 1991). In active learning the instructor is required to facilitate rather than control the learning process while enabling students' self-discovery (Bennett 2006). In this respect, research shows that both active and passive learning methods lead to similar levels of mastery of a subject, however, active learning can lead to improved cognitive outcomes in class-specific materials (Michel et al. 2009). Furthermore, active learning through student consultancy projects was found to enhance the development of skills in communication, teamwork, problem solving, and research, as well as the personal attributes of self-confidence and leadership (Thomas and Busby 2003).

The UiA Crowdfunding Lab course combines both passive and active learning methods in a complimentary manner. The course is organized as a series of eight full-day face-to-face sessions as described above. There is a split between frontal lectures in which instructors and guest lecturers present relevant information to participants, which is then followed by supervised and guided student consultancy project work, in which students implement what they have learned in the lecture into a real-life case work. This allows participants to both receive and apply knowledge while critically thinking about its applicability in the context of their concrete 
task at hand. The lectures follow the modules presented in Table 20.1 and are provided mostly by the UiA course instructor(s), while being supplemented by guest lecturers chosen for their expertise (e.g. FinTech industry, legal experts, video production specialists) or as representatives of key stakeholders (e.g. platform representatives and experienced fundraisers).

Student consultancy projects have been growing in popularity in a variety of business courses as they allow students an opportunity to integrate their academic and work experiences in the development of solutions for a client's real-world problems (Heriot et al. 2008). At the UiA Crowdfunding Lab, student project work is organized in groups. The groups are formed by the lecturers, who attempt to ensure heterogeneity in terms of nationalities, backgrounds, and gender, while at the same time accommodate one out of the students' top three project preferences. Each group is assigned to an external organization that signed up to partaking in the course with the objective of creating a crowdfunding campaign for one of their projects.

The group assignment follows a short introduction by the external organizations, based on which each student lists their top three or four preferred projects. This is important for keeping the student's motivation, as well as enhancing their sense of commitment based on their own optin. In most cases, diversity of interests ensures good spread of project preferences, especially when considering each student indicates multiple project preferences. Throughout the course, the groups are engaged in a structured process for developing a crowdfunding campaign and the writing-up of an execution plan for such campaign. At the end of the course, the students deliver a complete campaign ready for publication and an execution plan that case organizations can follow should they wish to take it live. The execution plan includes a structured analysis (incorporating both qualitative and quantitative elements) and explanation for critical decisions made about the campaign, as well as guidelines for its actual execution. Each decision corresponds to a relevant module in the course programme (discussed earlier in the chapter under 'content').

To ensure progress, and allow for timely interventions, groups present their achievements vis-à-vis stated expectations at four points in time throughout the course. Each presentation builds on the former, and students are expected to implement feedback received by evaluation panels 
in each round towards the coming presentation. The first presentation takes place on the second session and requires students to present (1) the case in terms of the product, service, or initiative of focus; (2) the problems the underlying product, service, or initiative aims to address or solve; and (3) the objectives of a prospective crowdfunding campaign in terms of understanding the financial and non-financial needs of the case organization.

The second presentation takes place on the fourth session and requires the students to present the same aspects as before and add the following: (4) the choice of crowdfunding model and platform; (5) a general project budget that includes a dedicated sub-budget specific to the crowdfunding campaign; (6) comparative analysis of similar or related historical campaigns including lessons that can be learned from them; and (7) the identification and characterization of target segments for campaign efforts, including their segment-specific communication channels (e.g. websites, online communities, magazines, forums, events).

The third presentation takes place during the sixth session requiring the updated presentation of all aspects covered earlier, while adding the following: (8) campaign value propositions (e.g. non-tangible benefits in donation crowdfunding, rewards in reward crowdfunding, loan terms in crowdlending, and ownership shares and share prices in equity crowdfunding); (9) campaign promotional plan (where, when, and what); (10) Gantt charts detailing campaign action points and schedule; and (11) campaign materials and visual elements including video, images, and main texts.

Finally, the fourth presentation involves a festive event with the participation of case organization representatives, external guests, and an expert panel in which students present their full campaign and plans. At the end of the process, an external evaluation panel, consisting of industry experts, academics, and public support organizations' representatives, announces a winning presentation that provides members of the winning group with certification and a small sum of money to be used on a joint group experience (e.g. dinner, entertainment). Course grading and assessments are done separately based on submitted materials. 


\section{Assessment}

According to Biggs (1996), educators are encouraged to achieve alignment between course objectives, teaching activities, and assessments in order to achieve maximum consistency throughout the process. Accordingly, assessment of learning occurs throughout the UiA Crowdfunding Lab course in the group project presentations listed earlier. Such presentations provide lecturers with multiple intervention points ensuring proper implementation of course materials in their project work. These interventions also allow students opportunities for constant improvement as well as a better understanding of their own progress.

The feedback provided for each presentation presents students with a 'reality check' better calibrating students' own assessments of their work with those of their instructors. From an instructor perspective, these interventions need to strike a delicate balance between 'bursting bubbles' and 'building steam' (Piperopoulos and Dimov 2015), providing students with critical feedback while avoiding both excessive praise and excessive criticism. The approach here is that everybody has opportunity to improve, albeit from differing progress levels, and all should be encouraged to achieve the best they can. Achievements should be recognized but opportunities for improvement should always be highlighted.

Actual grading only takes place at the end of the course based on a final presentation and all related submitted materials. Course grades are based on two components: $40 \%$-group delivery of crowdfunding campaign materials $+60 \%$-written group report and execution plan. Campaign materials include campaign texts, video, images, examples of social media posts, and any other supporting materials. The written execution plan includes the complete analyses behind all decisions made as well as a concrete list of action points and schedule for campaign management. The written plan is accompanied by the final presentation, which represents the highlights of the more detailed written report.

Table 20.2 outlines the expectations presented to course participants at the beginning of the course and serves as the template on which they 
Table 20.2 Crowdfunding course grading form

\begin{tabular}{|c|c|c|}
\hline Component & Content & $\begin{array}{l}\text { Percentage of } \\
\text { grade }\end{array}$ \\
\hline Need clarification & $\begin{array}{l}\text { What is the problem/need the concept } \\
\text { solves? } \\
\text { What evidence is there for the } \\
\text { prevalence of the problem/need? }\end{array}$ & $5 \%$ \\
\hline Concept description & $\begin{array}{l}\text { What is the product/service/initiative? } \\
\text { What is its core value proposition? }\end{array}$ & $2 \%$ \\
\hline $\begin{array}{l}\text { Campaign objectives } \\
\text { and financial needs }\end{array}$ & $\begin{array}{l}\text { Financial objectives of campaign } \\
\text { Non-financial objectives of campaign } \\
\text { Project financial plan } \\
\text { For investment campaigns-firm/ } \\
\text { organization financial plans }\end{array}$ & $7 \%$ \\
\hline $\begin{array}{l}\text { Model and platform } \\
\text { choices }\end{array}$ & $\begin{array}{l}\text { Crowdfunding model choice and why? } \\
\text { Platform choice and why? }\end{array}$ & $7 \%$ \\
\hline $\begin{array}{l}\text { Analyses of historical } \\
\text { campaigns }\end{array}$ & $\begin{array}{l}\text { Analysis of at least } 3 \text { similar or } \\
\text { relevant historical campaigns } \\
\text { What are the lessons from these } \\
\text { campaigns? }\end{array}$ & $3 \%$ \\
\hline $\begin{array}{l}\text { Market and segment } \\
\text { selections }\end{array}$ & $\begin{array}{l}\text { Criteria for choosing segments } \\
\text { Segment identification and definition } \\
\text { Segment profiling and characteristics }\end{array}$ & $5 \%$ \\
\hline $\begin{array}{l}\text { Competition and } \\
\text { positioning }\end{array}$ & $\begin{array}{l}\text { Comparison with competing concepts } \\
\text { along critical dimensions } \\
\text { What is the project concept's core } \\
\text { value proposition? } \\
\text { What is the project concept's unique } \\
\text { positioning? }\end{array}$ & $5 \%$ \\
\hline $\begin{array}{l}\text { Potential backer } \\
\text { survey and analyses }\end{array}$ & $\begin{array}{l}\text { What is currently used to address need } \\
\text { by segment? (reward) } \\
\text { Consumption preferences, capabilities, } \\
\text { and channels (reward) } \\
\text { Donation preferences, capabilities, } \\
\text { and channels (donation) } \\
\text { Investment preferences, capabilities, } \\
\text { and channels (investment) }\end{array}$ & $10 \%$ \\
\hline Execution plan & $\begin{array}{l}\text { Action points (what?), schedule } \\
\text { (when?), responsibility (who?) } \\
\text { Value propositions = concrete rewards } \\
\text { or investment offerings }\end{array}$ & $3 \%$ \\
\hline
\end{tabular}


Table 20.2 (continued)

\begin{tabular}{lll}
\hline Component & Content & $\begin{array}{l}\text { Percentage of } \\
\text { grade }\end{array}$ \\
\hline Campaign materials & Texts and images & $10 \%$ \\
& Video & $10 \%$ \\
& Social media posts & $5 \%$ \\
& PR and relevant communication & $5 \%$ \\
& channels & \\
& Relevant online communities & $5 \%$ \\
& Relevant bloggers, journalists, and \\
Total & $5 \%$ \\
& & $100 \%$ \\
\hline
\end{tabular}

develop their presentations and plans. The first two columns represent the content of expected presentation and written plan, while the third column represents a suggested grading scheme.

\section{Course Evaluation}

Denson et al. (2010) suggest that course evaluations are needed for improving attainment of learning outcomes. It is not the feedback about the teaching effectiveness that should matter the most, but rather the facilitation of student learning. The student evaluations from the UiA Crowdfunding Lab may provide important insights on the students' learning outcomes.

Out of the 29 master students participating in the course, 23 filled out the evaluation survey form. The results of which show how the students evaluate the way the course was taught, as well as their sense of learning. Here, students express high levels of satisfaction with $90 \%$ indicating the course was taught in an engaging way and 100\% indicating the course provided them with tools for building crowdfunding campaigns. In qualitative comments students mentioned the course provided them with a sense of learning, as well as expressed appreciation of the lecturers, and the experience of working with real companies and cases. Moreover, the student's expressed appreciation of feedback along the way, which allowed them to gradually improve their project work. They also indicated appreciation for the sense of challenge that they were exposed to during the 
course. In this respect, 6 of the 23 respondents voiced that they experienced time pressure and a demanding workload during the course.

Areas for improvement include better use of reading list, as $65 \%$ of students indicated not to have read most of the assigned readings, and $26 \%$ indicated not to have read most of the lecture slides. There seems to be agreement that the course load is demanding in certain aspects (e.g. group project) and less demanding in other aspects (limited reading lists and no need for individual exam preparation). In any case, all activities were accumulative so that students did not stretch across different tasks, but gradually improved the same task. Dealing with critical feedback, and continuous revision of earlier work multiple times throughout the course, may expose students to demands they are not used to from most other courses they take during their university education.

\section{Opportunities for Further Development}

The course programme presented in this chapter is one of the first of its kind; hence, opportunities and directions for further development and improvement are many. In this section several selected opportunities are highlighted. The first obvious opportunity, which has also surfaced in participants' feedback, is the need for a formalized textbook that can support the course. Currently, the combination of lecture slides and article reading lists while insightful and informative nevertheless lacks the coherence afforded by a structured textbook that students can follow. Most books currently available can be characterized as light readings focused on the hype around crowdfunding, and often lack academic rigour, balanced perspective, as well as critical review of related issues. In addition, a few research-oriented academic edited volumes are also available, but like reading lists, these represent a collection of studies into various aspects of crowdfunding, rather than generic and detailed overview of its fundamental aspects. Hence, there is a need and room for a dedicated textbook oriented towards students at educational institutions.

A second opportunity is in extending the course to a longer period, where students may also manage and follow the actual real-time campaign in partnership with the case organizations. Such extension would 
enhance dynamism and excitement of real-time results to the process and may even further enhance student commitments to their assigned projects. However, such opportunities are limited by regulations and rules. Specifically, as is the case of UiA in Norway, it is either impossible or outright prohibited for a publicly funded education institution to engage in fundraising activities on behalf of external commercial organizations. Such practice might be possible, however, in privately owned universities and institutions.

Nevertheless, when including real-time campaigning in the course programme, it is here recommended that actual grading of students would not be based on campaign financial results, but rather on whether they have created and managed a campaign in line with guidance provided during the course. This is because students should be evaluated on their learning outcomes rather than on actual business performance, which is often influenced by a plethora of external variables outside the students' control. Furthermore, this is especially true when the very concept the students have been working with was externally provided.

Alternatively, business education has seen a growth in the usage of business simulations as one form of active learning (Clarke 2009; Levant et al. 2016). Accordingly, brought into the crowdfunding context, campaign simulation software may be developed in accordance with best practice recommendations. Such simulations will ensure satisfactory campaign outcomes in a controlled environment, when students develop and manage a campaign in accordance with the teachings. Such tools may also allow for interventions throughout the campaign process simulating real-time challenges that can be addressed in class in a new module on 'trouble shooting' common problems during the campaign. In such cases, students' grading may be linked to campaign outcomes. However, a challenge here remains when using real-life cases, as simulations may not be able to predict and include all possible relevant conditions specific to such cases that may emerge from a variety of sectors, involving novel concepts, as well as addressing a wide range of potential segments.

A different development opportunity lies in extending the course's reach. Here an opportunity may exist in converting the existing academic course into a format better suited for executive education rather than full time degree programme students. Many of the potential entrepreneurs, 
artists, and social activists that may benefit from training in crowdfunding are mostly busy with their ventures and projects and are not available for a series of full-day sessions. Furthermore, such audience may be more concerned with practical skill development rather than with theoretical aspects or degree awarding credits. At the same time, many of those who require these skills may also be operating under severe resource constraints that may limit their ability to invest in training. Hence, a concise, practice-oriented, and affordable adult education programme may be created based on the existing programme, while serving practitioners. Furthermore, such training may also be co-financed by dedicated governmental support agencies, incubator managers, as well industry associations.

\section{Conclusion}

While many may have heard the term 'crowdfunding', much confusion and misunderstanding about its meaning and implications abound. In order to ensure a healthy and ethical development of the crowdfunding industry, it may be important to support better informed participants. This may be achieved by the offering of crowdfunding dedicated education programmes. A need for such programmes is also based on the growing demand for equipping students with knowledge and skills that may prove useful in their future employment in an ever more digitized age, while at the same time help them understand and develop group-work, flexible problem solving, and digital skills that may be applied in a variety of different contexts. Such objectives were accommodated in the presentation of a concrete course programme based on the Crowdfunding Lab format developed at UiA in Norway. For this purpose, the course objectives, content, pedagogy, and assessment procedures have been highlighted, while presenting how they align into a coherent educational effort.

In terms of implications for practice, the illustrative case presented in detail throughout this chapter may help inform similar course design and development efforts in other higher education institutions. Furthermore, some of the opportunities for further development represent an invitation for educators to both extend and refine a wider set of tools and 
educational formats for crowdfunding training. These include the development of a dedicated textbook and simulation exercises, as well as the extension of course content to incorporate real-time campaigning where regulations allow for that. In addition, an opportunity towards converting existing academic course format into an adult or executive education format has been outlined and may answer a market gap currently uncovered by platforms, educational institutions, or public agencies.

Finally, in terms of implications for research, in the absence of earlier research on crowdfunding education, opportunities abound. One line of research may seek to measure course impact on participants in terms of their sense of self-efficacy as well as attitudes towards crowdfunding following such educational experience. Furthermore, studies may examine whether participants in crowdfunding education programmes are more likely to engage in either fundraising activities using crowdfunding or in contributing financially to crowdfunding campaigns than individuals who did not participate in such programmes. A different measurement of impact may relate to performance of campaigns run by individuals who have taken crowdfunding training versus campaigners who did not take such training.

An additional research direction may seek to evaluate the effectiveness of various course components in achieving its stated objectives. Here, the relative importance and impact of course materials (whether textbooks, lecture slides, or reading lists), student consultancy project experiences, actual campaign material development, and the introduction to industry stakeholders (e.g. platform representatives, successful campaigners), each may carry different influence that may align with course objectives. Such insights will be helpful for further course development and fine-tuning.

Lastly, research identifying the necessary adjustments to course content, pedagogy, and assessment tools in different contexts, as defined by their cultural, institutional, sectoral, and economic development conditions may also be helpful for effective educational experiences. Here, it is important to acknowledge that contextual conditions may vary significantly from one context to another and may require adjustments to ensure a better fit to local conditions, and hence improve students' ability to relate and engage in the course. 


\section{References}

Ajzen, I. (1991). The Theory of Planned Behavior. Organizational Behavior and Human Decision Process, 50(2), 179-211.

Alois, J. D. (2018). UiA: Norwegian University Launches Master's Elective Crowdfunding Lab Course. Retrieved January 29, 2020, from https:// www.crowdfundinsider.com/2018/10/139881-uia-norwegian-universitylaunches-masters-elective-crowdfunding-lab-course/.

Bandura, A. (1986). The Explanatory and Predictive Scope of Self-Efficacy Theory. Journal of Social and Clinical Psychology, 4(3), 359-373.

Bennett, R. (2006). Business Lecturers' Perceptions of the Nature of Entrepreneurship. International Journal of Entrepreneurial Behavior \& Research, 12(3), 165-188.

Biggs, J. (1996). Enhancing Teaching Through Constructive Alignment. Higher Education, 32(3), 347-364.

Boeuf, B., Darveau, J., \& Legoux, R. (2014). Financing Creativity: Crowdfunding as a New Approach for Theatre Projects. International Journal of Arts Management, 16(3), 33-48.

Bonwell, C., \& Eison, J. (1991). Active Learning: Creating Excitement in the Classroom (ASHE-ERIC Higher Education Report No 1). Washington, DC: George Washington University.

Brocato, E. D., White, N. J., Bartkus, K., et al. (2015). Social Media and Marketing Education: A Review of Current Practices in Curriculum Development. Journal of Marketing Education, 37(2), 76-87.

Bruton, G., Khavul, S., Siegel, D., et al. (2015). New Financial Alternatives in Seeding Entrepreneurship: Microfinance, Crowdfunding, and Peer-to-Peer Innovations. Entrepreneurship Theory and Practice, 39(1), 9-26.

Business.gov.au. (2019). How to Crowdfund Your Business. Australian Government. Retrieved from https://www.business.gov.au/Finance/Seekingfinance/How-to-crowdfund-your-business.

Chaney, D. (2019). A Principal-Agent Perspective on Consumer Co-production: Crowdfunding and the Redefinition of Consumer Power. Technological Forecasting and Social Change, 141, 74-84.

Clarke, E. (2009). Learning Outcomes from Business Simulation Exercises: Challenges for the Implementation of Learning Technologies. Education + Training, 51(5/6), 448-459. 
Consumer.ftc.gov. (2019). Understanding Crowdfunding. US Federal Trade Commission. Retrieved from https://www.consumer.ftc.gov/articles/ understanding-crowdfunding.

Crittenden, V. L., \& Crittenden, W. F. (2006). The Undergraduate Capstone Marketing Course: Objectives, Content, and Pedagogy. Journal for Advancement of Marketing Education, 8, 79-88.

De Buysere, K., Gajda, O., Kleverlaan, R., et al. (2012). A Framework for European Crowdfunding. Retrieved from https:/www.fundraisingschool.it/ wp-content/uploads/2013/02/European-Crowdfunding-FrameworkOct-2012.pdf.

De Faoite, D., Henry, C., Johnston, K., et al. (2003). Education and Training for Entrepreneurs: A Consideration of Initiatives in Ireland and The Netherlands. Education + Training, 45(8/9), 430-438.

De Voldere, I., \& Zeqo, K. (2017). Crowdfunding: Reshaping the Crowd's Engagement in Culture. Brussels: European Commission.

Denson, N., Loveday, T., \& Dalton, H. (2010). Student Evaluation of Courses: What Predicts Satisfaction? Higher Education Research \& Development, 29(4), 339-356.

European Commission. (n.d.). Crowdfunding Explained. Brussels: European Commission. Retrieved from https://ec.europa.eu/growth/tools-databases/ crowdfunding-guide/what-is/explained_en.

Fox, J., Bartholomae, S., \& Lee, J. (2005). Building the Case for Financial Education. Journal of Consumer Affairs, 39(1), 195-214.

Graeff, T. R. (1998). Writing Behavioral Learning Objectives for Marketing Courses: Meeting the Challenge of AACSB Outcomes Assessment. Marketing Education Review, 8(1), 13-25.

Griffin, P., \& Care, E. (2014). Assessment and Teaching of 21st Century Skills: Methods and Approach. Dordrecht: Springer.

Haddad, C., \& Hornuf, L. (2019). The Emergence of the Global Fintech Market: Economic and Technological Determinants. Small Business Economics, 53(1), 81-105.

Harrigan, P., \& Hulbert, B. (2011). How Can Marketing Academics Serve Marketing Practice? The New Marketing DNA as a Model for Marketing Education. Journal of Marketing Education, 33(3), 253-272.

Heriot, K. C., Cook, R., Jones, R. C., et al. (2008). The Use of Student Consulting Projects as an Active Learning Pedagogy: A Case Study in a Production/Operations Management Course. Decision Sciences Journal of Innovative Education, 6(2), 463-481. 
Innovation Norway. (n.d.). Innovation Norway [Online]. Oslo: Innovation Norway. Retrieved January 30, 2020, from https://www.innovasjonnorge. no/en/start-page/.

Jegelevičiūtė, S., \& Valančienè, L. (2015). Comparative Analysis of the Ways Crowdfunding Is Promoted. Procedia - Social and Behavioral Sciences, 213, 268-274.

Levant, Y., Coulmont, M., \& Sandu, R. (2016). Business Simulation as an Active Learning Activity for Developing Soft Skills. Accounting Education, 25(4), 368-395.

Michel, N., Cater Iii, J. J., \& Varela, O. (2009). Active Versus Passive Teaching Styles: An Empirical Study of Student Learning Outcomes. Human Resource Development Quarterly, 20(4), 397-418.

Mwasalwiba, E. S. (2010). Entrepreneurship Education: A Review of Its Objectives, Teaching Methods, and Impact Indicators. Education + Training, 52(1), 20-47.

Piperopoulos, P., \& Dimov, D. (2015). Burst Bubbles or Build Steam? Entrepreneurship Education, Entrepreneurial Self-Efficacy, and Entrepreneurial Intentions. Journal of Small Business Management, 53(4), 970-985.

Shneor, R., \& Munim, Z. H. (2019). Reward Crowdfunding Contribution as Planned Behaviour: An Extended Framework. Journal of Business Research, 103, 56-70.

Simpson, T. (2013). The Relevance of Higher Education: Exploring a Contested Notion. Plymouth: Lexington Books.

Thomas, S., \& Busby, S. (2003). Do Industry Collaborative Projects Enhance Students' Learning? Education + Training, 45(4), 226-235.

Wingfield, S. S., \& Black, G. S. (2005). Active Versus Passive Course Designs: The Impact on Student Outcomes. Journal of Education for Business, 81(2), 119-123. 
Open Access This chapter is licensed under the terms of the Creative Commons Attribution 4.0 International License (http://creativecommons.org/licenses/ by/4.0/), which permits use, sharing, adaptation, distribution and reproduction in any medium or format, as long as you give appropriate credit to the original author(s) and the source, provide a link to the Creative Commons licence and indicate if changes were made.

The images or other third party material in this chapter are included in the chapter's Creative Commons licence, unless indicated otherwise in a credit line to the material. If material is not included in the chapter's Creative Commons licence and your intended use is not permitted by statutory regulation or exceeds the permitted use, you will need to obtain permission directly from the copyright holder.

(c) $\underset{8 \mathrm{BY}}{(1)}$ 